\title{
Relationships between Viscosity and the Contents of Macromolecular Substances from Milk with Different Storage Styles
}

\author{
Ku Ting, Yong-Feng Liu*, Gao Tian-Li, Zhao Lu-Hua \\ College of Food Engineering and Nutritional Science, Shaanxi Normal University, China
}

Copyright $(2016$ by authors, all rights reserved. Authors agree that this article remains permanently open access under the terms of the Creative Commons Attribution License 4.0 International License

\begin{abstract}
Relationships between viscosity and the contents of macromolecular substances (milk protein, casein, whey protein and milk fat) from raw milk were studied at the temperature of $2-5^{\circ} \mathrm{C}$ (a storage temperature in a household refrigerator), $10^{\circ} \mathrm{C}$ and $20^{\circ} \mathrm{C}$ (a near-room temperature) during milk storage. An approach by means of mathematical models was used in this study to analyze the relationships between the viscosity and the contents of these macromolecular substances from milk at the three temperatures. The results indicated that the milk viscosity initially remained quite steady for a period of time, followed by an increase for a short-period, then a decrease during the subsequent days, and had a sharp rise in the final days at the temperatures of $10^{\circ} \mathrm{C}$ and $20^{\circ} \mathrm{C}$, while the viscosity of milk stored at the temperature of $2-5^{\circ} \mathrm{C}$ presented a decrease initially and a sharp rise in the final days. Significant correlations were also found between the value of viscosity and the contents of macromolecular substances along with storage time extended at the three temperatures. The correlation models based on the viscosity and the contents of macromolecular substances had good fit with high correlation coefficients $\left(\mathrm{R}^{2}>0.8000\right)$ and could well explain the relevance of viscosity and the contents of macromolecular substances at a significance level that was less than or equal to 0.0067 . Meanwhile, these correlation models contributed to a better understanding of the change of milk system during storage in view of providing tools to develop high quality dairy products with desirable characteristics, and could also be useful in process design and control, as well as quality control and real-time monitoring of deterioration of the raw milk.
\end{abstract}

Keywords Milk, Viscosity, Storage Temperature and Time, Macromolecular Substances, Mathematical Models

\section{Introduction}

Nutrient-rich milk is an excellent source of protein, lipids, lactose, minerals and vitamins ${ }^{[1]}$ and also a natural medium as well as easy to spoilage when in storage. Consumer acceptance of milk is highly depended on its consistency, which requires information about the rheological behaviors. Viscosity, a rheological property, is considered as an important physical characteristic for assessing the quality change of milk during storage ${ }^{[2-4]}$. Milk viscosity varied in degree of its constituents depending on changes of chemical and physical properties. Milk underwent numerous physical, chemical and biological processes during storage that had influences on its technological properties contributing to change of milk viscosity ${ }^{[5]}$. In addition, excessively long storage or storage under improper conditions would be the cause of a viscosity change in milk ${ }^{[6]}$.

Variation of milk viscosity during storage is mainly depended on some macromolecular substances including milk protein, casein, whey protein and milk fat content ${ }^{[7-9]}$, but whether the variation continued would be depended firstly on which type of flow conditions of milk was remained. Milk was a kind of known natural oil in water $(\mathrm{o} / \mathrm{w})$ emulsion with the milk fat globules acting as the dispersed phase, which was shown to behave as non-Newtonian fluids ${ }^{[10]}$, and that tended to result in a change in milk viscosity when the content of milk fat changed. Also, milk fat changed fastest among all the components, followed by protein ${ }^{[11]}$. Casein constituted up to $80 \%$ of total proteins of milk, and formed colloidal particles known as casein micelles ${ }^{[12]}$. The stability of casein micelles played a crucial role in the overall properties of milk ${ }^{[13,14]}$. Retention of the unique properties of casein complex was a main problem to face the change in milk quality during milk storage ${ }^{[12]}$.

Milk metamorphism was a complex process that could be divided into four stages: including reduction of bacteria, acidogenic fermentation, neutralization and the final stage of decomposition and corruption. The acidic condition of milk stretched the casein molecules into linear form and then intertwined into a network structure in the stage of acidogenic fermentation. Whey proteins were also separated 
from casein curds in this stage. Milk transformed from emulsion to clear liquids at the stage of decomposition and corruption due to the decomposition of casein and fat in milk. Meanwhile, viscosity of milk changed with its components while the essential reasons were that the $\mathrm{pH}$ of the milk changed during these stages. Besides, the denatured whey proteins tended to form whey/casein complexes on the basis of the $\mathrm{pH}$ of environment and the proximity of available molecules that contributed to viscosity change ${ }^{[15-17]}$. Furthermore, milk acidification dissolved colloidal $\mathrm{Ca}$ phosphate and increased the $\mathrm{Ca}^{2+}$ activity, which reduced the repulsion among the negatively charged caseins and resulted in an effect on viscosity ${ }^{[13]}$.

Based on the importance of viscosity in studying the change of milk constituents, milk was subjected to family storage styles. Measurements of viscosity have been recognized necessary to provide fundamental insights on rheological property of milk. To the knowledge of the authors, few studies have reported the combined effect of the storage temperatures and time on the variation of milk viscosity, as well as the relationships between viscosity and macromolecular substances in milk during the process of milk storage. Therefore, we examined the viscosity and the contents of macromolecular substances from raw milk at the temperature of $2-5^{\circ} \mathrm{C}$ (a storage temperature in a household refrigerator), $10^{\circ} \mathrm{C}$ and $20^{\circ} \mathrm{C}$ (a near-room temperature) during storage and analyzed the relationships between viscosity and macromolecular substances from raw milk in this study. The objective of this work was thus to contribute to a better understanding of the change of milk system during storage in view to provide tools to develop high quality dairy products with desirable characteristics, and this could also be useful in quality control and real-time monitoring of deterioration of the raw milk.

\section{Materials and Methods}

\subsection{Samples and Grouping}

Representative milk samples without preservative were collected from a healthy adult Chinese Holstein cow in the morning. A total of 145 milk samples were prepared and divided into three groups randomly. The indicators including milk viscosity, milk protein, casein, whey protein and milk fat were measured when the milk samples were stored at temperatures of $2-5^{\circ} \mathrm{C}, 10^{\circ} \mathrm{C}$, and $20^{\circ} \mathrm{C}$ for a specified number of days. Because low temperature was beneficial to maintain the viscosity, indicators were measured once every day at $2-5^{\circ} \mathrm{C}$, but three times per day at $10^{\circ} \mathrm{C}$ and $20^{\circ} \mathrm{C}$. Measurement of the three-time interval was prescribed for three hours in one day. Indicators measurements were terminated when milk showed obvious metamorphism, including fat floating, protein sedimentation and coagulation, whey separation, sour, and color-taste-flavor changed.

\subsection{Milk Protein and Milk Fat Content Measurements}

The contents of milk protein and milk fat $\left(\mathrm{g} \cdot 100 \mathrm{ml}^{-1}\right)$ were measured with Lactoscan (MLA50, MCC, Bulgaria). The measurements were conducted at a temperature of $25 \pm 3^{\circ} \mathrm{C}$.

\subsection{Viscosity Measurement}

The milk viscosity was measured by a Viscometer (RVDV-II+Pro, Brookfield, Massachusetts, USA) equipped with a thermostatically controlled water. A SC4-27 type rotor with 200rpm rotation speed was chosen. All measurements were conducted at $25 \pm 0.1^{\circ} \mathrm{C}$. Additionally, milk samples would be shaking gently by the same person when milk was delaminated and deposited slightly for reducing measurement error and maintaining the viscosity not fluctuated.

\subsection{Determination of Casein}

Milk samples were centrifuged at 2900r/min for $15 \mathrm{mins}$ at room temperature, and the top layer (cream) was removed by scraping, leaving bottom layer behind. $4.0 \mathrm{ml}$ of acetic acid-sodium acetate buffer solution $\left(0.2 \mathrm{~mol} \cdot \mathrm{l}^{-1}, \mathrm{pH} 4.6\right)$ was added into $1.0 \mathrm{ml}$ of bottom liquid with sufficient mixing. The mixture was held for 30 minutes before being centrifuged at $1300 \mathrm{r} / \mathrm{min}$ for 10 mins. After discarding the supernatant, $1.0 \mathrm{ml}$ of acetic acid-sodium acetate buffer solution was added to the tube. The supernatant was discarded after being centrifuged at $1300 \mathrm{r} / \mathrm{min}$ for $10 \mathrm{mins}$. The sediment was dissolved in sodium hydroxide solution $\left(0.05 \mathrm{~mol} \cdot \mathrm{l}^{-1}\right)$ and diluted to $10 \mathrm{~m} 1$ in a volumetric flask. 1.0 $\mathrm{ml}$ of the above solution was mixed with $4.0 \mathrm{ml}$ of biuret reagent and held for 30 mins before being tested in the spectrophotometer. Finally, the content of casein was calculated according to the standard curve.

\subsection{Standard Curve Drawing of Casein}

Standard curve was drawn according to Ellman et al. ${ }^{[18]}$. The main experimental procedure was as follows: a volume of $0.0,0.2,0.4,0.6,0.8$ and $1.0 \mathrm{ml}$ of casein standard solution $\left(10 \mathrm{mg} \cdot \mathrm{ml}^{-1}\right.$, Sigma, USA) was pipetted into a test tube, respectively. If casein standard solution was less than 1 $\mathrm{ml}$, distilled water was added to make the casein standard solution up to $1 \mathrm{ml} .4 \mathrm{ml}$ of biuret reagent was added and incubated for $30 \mathrm{mins}$ at room temperature after well mixed. A UV-Vis spectrophotometer (TU-181, Beijing Purkinje General Instrument Company, China) was used to measure the absorbance value of the solution at $540 \mathrm{~nm}$. A standard curve was drawn with the content of casein as abscissas and the absorbance value as ordinate.

\subsection{Whey Protein Calculation}

The content of whey protein was calculated as follows: 


$$
\begin{gathered}
m_{2}=m-m_{1} \\
c=m_{2} / V
\end{gathered}
$$

Where $c$ was the content of whey protein $\left(\mathrm{g} \cdot 100 \mathrm{ml}^{-1}\right) ; V$ was the volume of milk sample $(100 \mathrm{ml}) ; m$ was the mass of milk protein $(\mathrm{g}) ; m_{l}$ was the mass of casein $(\mathrm{g}) ; m_{2}$ was the mass of whey protein $(\mathrm{g})$.

\subsection{Statistical Analysis}

The analysis of variance (ANOVA) was used to detect differences between mean values of indexes in SPSS (Version 14.0, SPSS Inc.). The models for the relationship between the content of macromolecular substances and milk viscosity were also analyzed by the same software. The goodness of fit of each model was ascertained considering coefficient of determination $\left(\mathrm{R}^{2}\right)$.

\section{Results}

\subsection{Standard Curve for Determination of Casein}

The regression equation of standard curve was $\mathrm{Y}=0.9024$ $\mathrm{X}+0.0267\left(\mathrm{R}^{2}=0.9982 ; \mathrm{Y}\right.$, the absorbance values; $\mathrm{X}$, the content of casein standard solution, $\mathrm{mg} \cdot \mathrm{ml}^{-1}$ ). As seen from Fig. 1, six points were almost collinear, which showed that the standard curve could be used to reflect the content of casein accurately.

\subsection{Effect of Storage Time and Temperature on Viscosity}

The milk viscosity changed at the three experimental temperatures as storage time extended, and their trends were as follows: the viscosity of milk initially remained quite steady for a period of time, followed by an increase for a short-period, then a decrease during the subsequent days, and had a sharp rise in the final days at the temperatures of $10^{\circ} \mathrm{C}$ and $20^{\circ} \mathrm{C}$. While the viscosity of milk stored at the temperature of $2-5^{\circ} \mathrm{C}$ presented a decrease initially and a sharp rise in the final days (Table 1). At $2-5^{\circ} \mathrm{C}$, the viscosity ranged from 1.00 to $2.63 \mathrm{mpa} \cdot \mathrm{s}$ during the first 10 days (Table 1). The value of viscosity fluctuated in the first five days, but did not differ significantly $(p>0.05)$. Viscosity began to present a descending trend after 6 days, reaching the minimum values on the $10^{\text {th }}$ day, and the change of viscosity was significant $(p<0.05)$. The viscosity began to rise again on the $10^{\text {th }}$ day and reached the maximum values of 9.05 mpa.s on the $15^{\text {th }}$ day, which was also significantly greater than that in the first ten days. The standard deviation (SD) was quite large on the $15^{\text {th }}$ day for the reason that obvious inhomogeneity occurred to milk.

Milk samples could be stored in a much shorter period at the temperatures of $10^{\circ} \mathrm{C}$ and $20^{\circ} \mathrm{C}$ than that at $2-5^{\circ} \mathrm{C}$ before they became seriously spoiled. The milk viscosity ranged from 1.39 to $3.47 \mathrm{mpa} \cdot \mathrm{s}$ during the first 63 hours when stored at $10^{\circ} \mathrm{C}$ (Table 1 ). There was no change in milk viscosity in the first 30 hours, while it increased significantly at the $42^{\text {nd }}$ hour $(p<0.05)$, and then decreased significantly until the $63^{\text {rd }}$ hour when it reached the minimum value $(p<0.05)$, followed by an abrupt increase until it reached the maximum value of $9.17 \mathrm{mpa} \cdot \mathrm{s}$ at the $66^{\text {th }}$ hour.

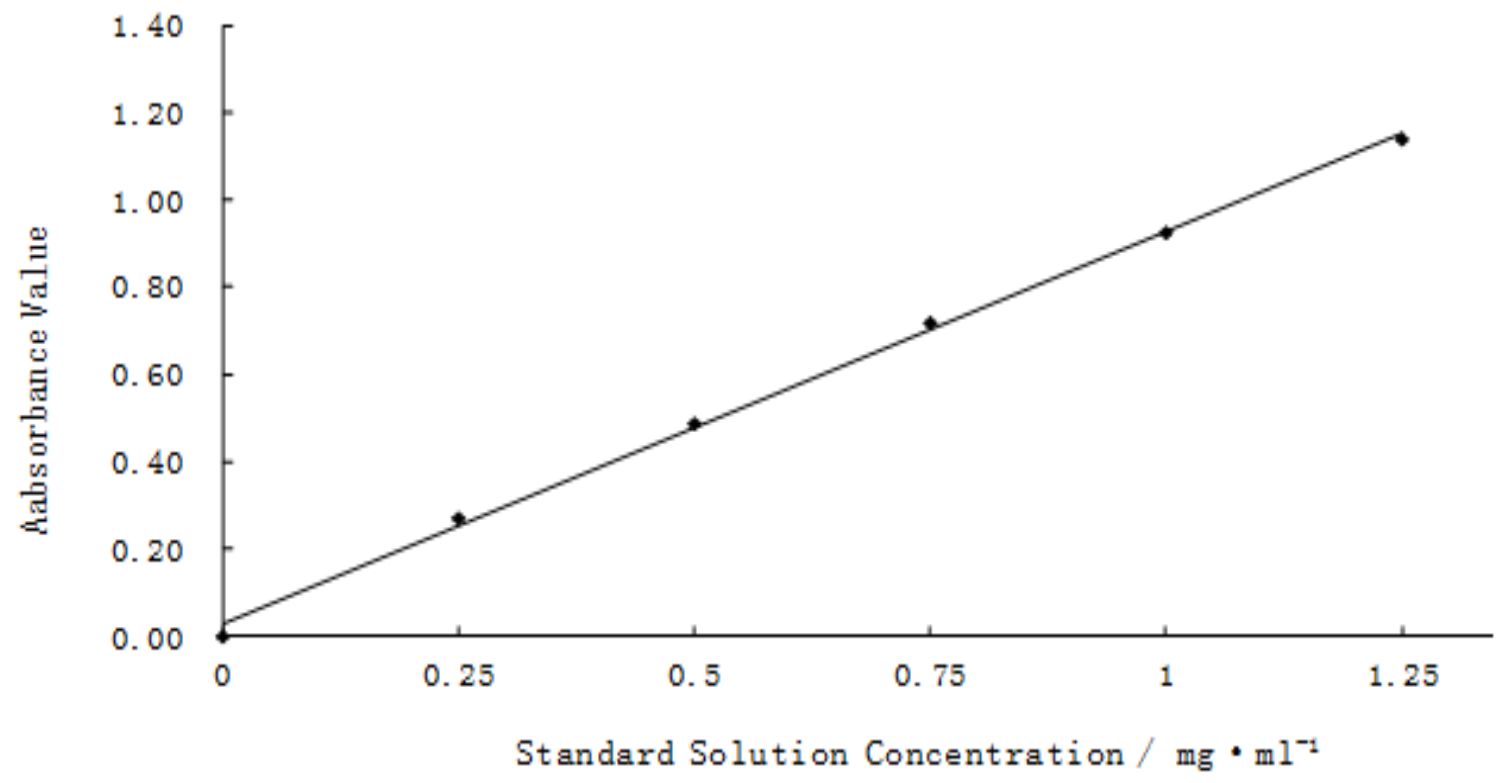

Figure 1. Standard curve of casein content and absorbance value at $540 \mathrm{~nm}$ 
Table 1. Milk viscosity as affected by storage time at the temperature of $2-5^{\circ} \mathrm{C}, 10^{\circ} \mathrm{C}$ and $20^{\circ} \mathrm{C}$

\begin{tabular}{|c|c|c|c|c|c|}
\hline $\begin{array}{l}\text { Storage Time at } \\
2-5^{\circ} \mathrm{C} \text { (day) }\end{array}$ & $\begin{array}{l}\text { Viscosity } \pm \text { SD } \\
(\mathrm{mpa} \cdot \mathrm{s})\end{array}$ & $\begin{array}{c}\text { Storage Time at } 10^{\circ} \mathrm{C} \\
\text { (hour) }\end{array}$ & $\begin{array}{l}\text { Viscosity } \pm \text { SD } \\
(\mathrm{mpa} \cdot \mathrm{s})\end{array}$ & $\begin{array}{c}\text { Storage Time at } 20^{\circ} \mathrm{C} \\
\text { (hour) }\end{array}$ & $\begin{array}{l}\text { Viscosity } \pm \text { SD } \\
(\mathrm{mpa} \cdot \mathrm{s})\end{array}$ \\
\hline 0 & $2.50 \pm 0.00^{\mathrm{bc}}$ & 0 & $2.50 \pm 0.00^{\text {cd }}$ & 0 & $2.5 \pm 0.00^{\mathrm{b}}$ \\
\hline 1 & $2.50 \pm 0.00^{\mathrm{bc}}$ & 3 & $2.50 \pm 0.00^{\text {cd }}$ & 3 & $2.5 \pm 0.00^{\mathrm{b}}$ \\
\hline 2 & $2.52 \pm 0.04^{\mathrm{bc}}$ & 6 & $2.50 \pm 0.00^{\text {cd }}$ & 6 & $2.45 \pm 0.00^{\mathrm{b}}$ \\
\hline 3 & $2.63 \pm 0.00^{b}$ & 9 & $2.57 \pm 0.02^{\mathrm{cd}}$ & 9 & $2.65 \pm 0.00^{b}$ \\
\hline 4 & $2.57 \pm 0.03^{\mathrm{bc}}$ & 21 & $2.50 \pm 0.00^{\mathrm{cd}}$ & 21 & $2.55 \pm 0.08^{b}$ \\
\hline 5 & $2.36 \pm 0.13^{\mathrm{bc}}$ & 24 & $2.50 \pm 0.00^{\mathrm{cd}}$ & 24 & $3.11 \pm 0.54^{b}$ \\
\hline 6 & $2.24 \pm 0.15^{\mathrm{bcd}}$ & 27 & $2.50 \pm 0.00^{\text {cd }}$ & 27 & $1.41 \pm 0.02^{\mathrm{b}}$ \\
\hline 7 & $1.70 \pm 0.37^{\text {bcde }}$ & 30 & $2.50 \pm 0.00^{\text {cd }}$ & 30 & $19.78 \pm 4.60^{\mathrm{b}}$ \\
\hline 8 & $1.45 \pm 0.06^{\mathrm{cde}}$ & 42 & $3.47 \pm 0.00^{\mathrm{b}}$ & I & 1 \\
\hline 9 & $1.26 \pm 0.01^{\mathrm{de}}$ & 45 & $3.02 \pm 0.02^{\mathrm{bc}}$ & 1 & 1 \\
\hline 10 & $1.00 \pm 0.00^{\mathrm{e}}$ & 48 & $2.74 \pm 0.04^{\text {cd }}$ & 1 & 1 \\
\hline 15 & $9.05 \pm 1.98^{\mathrm{a}}$ & 51 & $2.30 \pm 0.13^{\mathrm{d}}$ & 1 & 1 \\
\hline 1 & I & 63 & $1.39 \pm 0.06^{\mathrm{e}}$ & I & 1 \\
\hline I & / & 66 & $9.17 \pm 1.44^{\mathrm{a}}$ & / & I \\
\hline
\end{tabular}

Note: $\mathrm{a}, \mathrm{b}, \mathrm{c}, \mathrm{d}$, e means with different superscripts were significantly different $(\mathrm{P}<0.05)$;

"/" represents the milk viscosity was unmeasured at corresponding temperature and time.

Milk samples could be stored in an even shorter period at $20{ }^{\circ} \mathrm{C}$ than that at $10{ }^{\circ} \mathrm{C}$. The viscosity ranged from 1.41 to $3.11 \mathrm{mpa} \cdot \mathrm{s}$ during the first 27 hours at the temperature of $20^{\circ} \mathrm{C}$ (Table 1 ). Viscosity had no change in the first 21 hours $(p>0.05)$, but an increase occurred at the $24^{\text {th }}$ hour $(p<0.05)$, followed insignificantly decreased $(p>0.05)$ for the next 3 hours, and then presented a sharp increase at the $30^{\text {th }}$ hour, reaching the maximum value of $19.78 \mathrm{mpa} \cdot \mathrm{s}$.

Overall, the milk viscosity changed regularly when the temperature changed. The result indicated that deteriorating time of milk could be delayed when milk was stored at a relatively low temperature.

\subsection{Relationship between Milk Protein Content and Viscosity during Storage}

The models had been proposed to find the relationship between the content of milk protein and viscosity at the temperature of $10^{\circ} \mathrm{C}$ and $20^{\circ} \mathrm{C}$ by method of polynomial

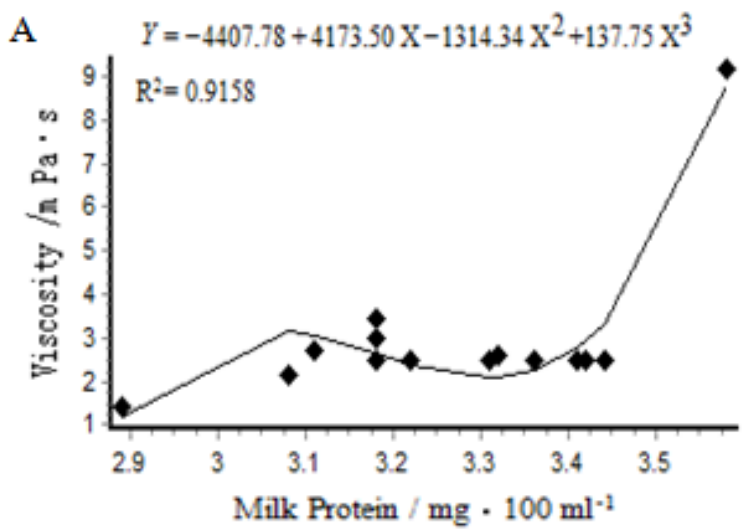

fitting and model equations were as follows: Equation 1A and Equation 1B. The models had good fit with high correlation coefficients $\left(\mathrm{R}^{2}=0.9158\right.$ for $10^{\circ} \mathrm{C}$ and 0.9954 for $20^{\circ} \mathrm{C}$ ). The two models could well explain the relationship between milk protein content and viscosity at a significance level of 0.0001 (Fig. 2A and Fig. 2B).

$$
Y=-4407.78+4173.50 \mathrm{X}-1314.34 \mathrm{X}^{2}+137.75 \mathrm{X}^{3}
$$

(Equation 1A)

Where; $\mathrm{X}=$ milk protein content $\left(\mathrm{g} \cdot 100 \mathrm{ml}^{-1}\right)$ at the temperature of $10^{\circ} \mathrm{C}, \mathrm{Y}=$ the value of viscosity $(\mathrm{mpa} \cdot \mathrm{s})$.

$$
Y=-29880.81+27233.22 \mathrm{X}-8262.75 \mathrm{X}^{2}+834.71 \mathrm{X}^{3}
$$

(Equation 1B)

Where; $\mathrm{X}=$ milk protein content $\left(\mathrm{g} \cdot 100 \mathrm{ml}^{-1}\right)$ at the temperature of $20^{\circ} \mathrm{C}, \mathrm{Y}=$ the value of viscosity (mpa $\left.\cdot \mathrm{s}\right)$.

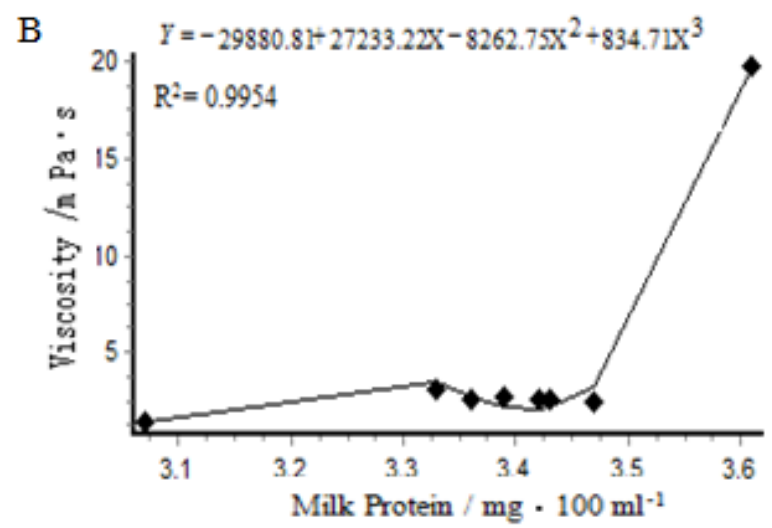

Note: points in figure showed a certain content of milk protein corresponded to a value of milk viscosity at the same storage temperature and time.

Figure 2. Correlation between milk viscosity and milk protein content during storage. A and B were the correlation between the content of milk protein and viscosity in the temperature of $10^{\circ} \mathrm{C}$ and $20^{\circ} \mathrm{C}$, respectively. 


\subsection{Relationship between Casein Content and Milk Viscosity during Storage}

The models had been proposed to find the relationship between casein content and viscosity at the temperature of $10^{\circ} \mathrm{C}$ and $20^{\circ} \mathrm{C}$ by method of Morgan Mercer Florin and model equations were as follows: Equation 2A and Equation 2B. The models had good fit with high correlation coefficients $\left(\mathrm{R}^{2}=0.9777\right.$ and 0.9958 , respectively). And the two models could well explain the relationship between casein content and viscosity at a significance level of 0.0001 (Fig. 3A and Fig. 3B).

$$
Y=-\left(8.16^{*}-57745384.46+2.67 \mathrm{X}^{50.84}\right) /\left(-57745384.46+\mathrm{X}^{50.84}\right)
$$

(Equation 2A)

Where; $\mathrm{X}=$ casein content $\left(\mathrm{g} \cdot 100 \mathrm{ml}^{-1}\right)$ at the temperature of $10^{\circ} \mathrm{C}, \mathrm{Y}=$ the value of viscosity $(\mathrm{mpa} \cdot \mathrm{s})$.

$$
Y=\left(2.32 *-3.60+2.33 * x^{3.58}\right) /\left(-3.60+x^{3.58}\right)
$$

Where; $\mathrm{X}=$ casein content $\left(\mathrm{g} \cdot 100 \mathrm{ml}^{-1}\right)$ at the temperature of $20^{\circ} \mathrm{C}, \mathrm{Y}=$ the value of viscosity (mpa $\bullet$ ).

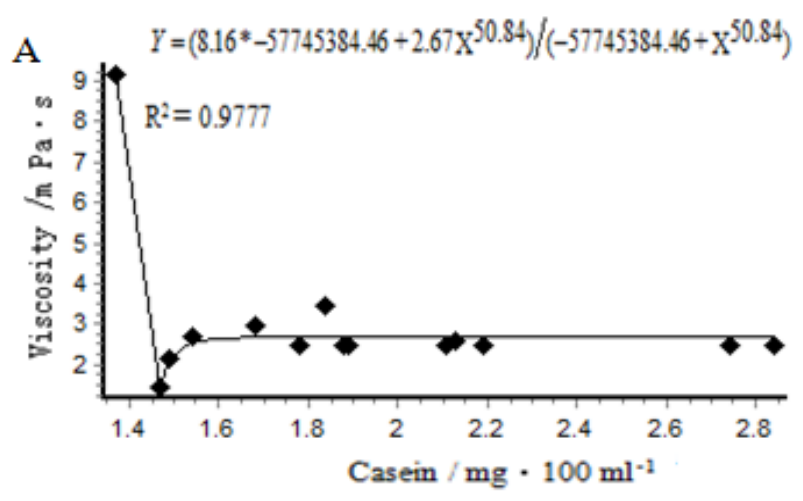

\subsection{Relationship between Whey Protein Content and Milk Viscosity during Storage}

The models had been proposed to find the relationship between whey protein content and viscosity at the temperature of $10^{\circ} \mathrm{C}$ and $20^{\circ} \mathrm{C}$ and by method of polynomial fitting and model equations were as follows: Equation $3 \mathrm{~A}$ and Equation 3B. The models had good fit with high correlation coefficients $\left(\mathrm{R}^{2}=0.9399\right.$ and 0.9397, respectively). And the two models could well explain the relationship between casein content and viscosity at a significance level of 0.0067 (Fig. 4A and Fig. 4B).

$$
Y=-5.97+25.72 \mathrm{X}-23.65 \mathrm{X}^{2}+6.83 \mathrm{X}^{3} \quad \text { (Equation 3A) }
$$

Where; $X=$ whey protein content $\left(\mathrm{g} \cdot 100 \mathrm{ml}^{-1}\right)$ at the temperature of $10^{\circ} \mathrm{C}, \mathrm{Y}=$ the value of viscosity (mpa $\left.\cdot \mathrm{s}\right)$.

$Y=-15.52+65.86 \mathrm{X}-67.64 \mathrm{X}^{2}+20.47 \mathrm{X}^{3} \quad$ (Equation 3B)

Where; $\mathrm{X}=$ whey protein content $\left(\mathrm{g} \cdot 100 \mathrm{ml}^{-1}\right)$ at the temperature of $20^{\circ} \mathrm{C}, \mathrm{Y}=$ the value of viscosity (mpa $\left.\cdot \mathrm{s}\right)$.

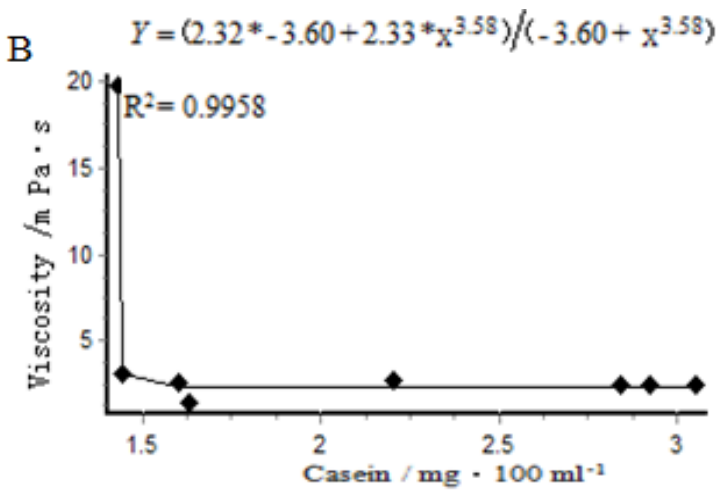

Note: points in figure showed a certain content of casein corresponded to a value of milk viscosity at the same storage temperature and time.

Figure 3. Correlation between milk viscosity and casein content during storage. A and B were the correlation between the content of casein and viscosity in the temperature of $10^{\circ} \mathrm{C}$ and $20^{\circ} \mathrm{C}$, respectively.
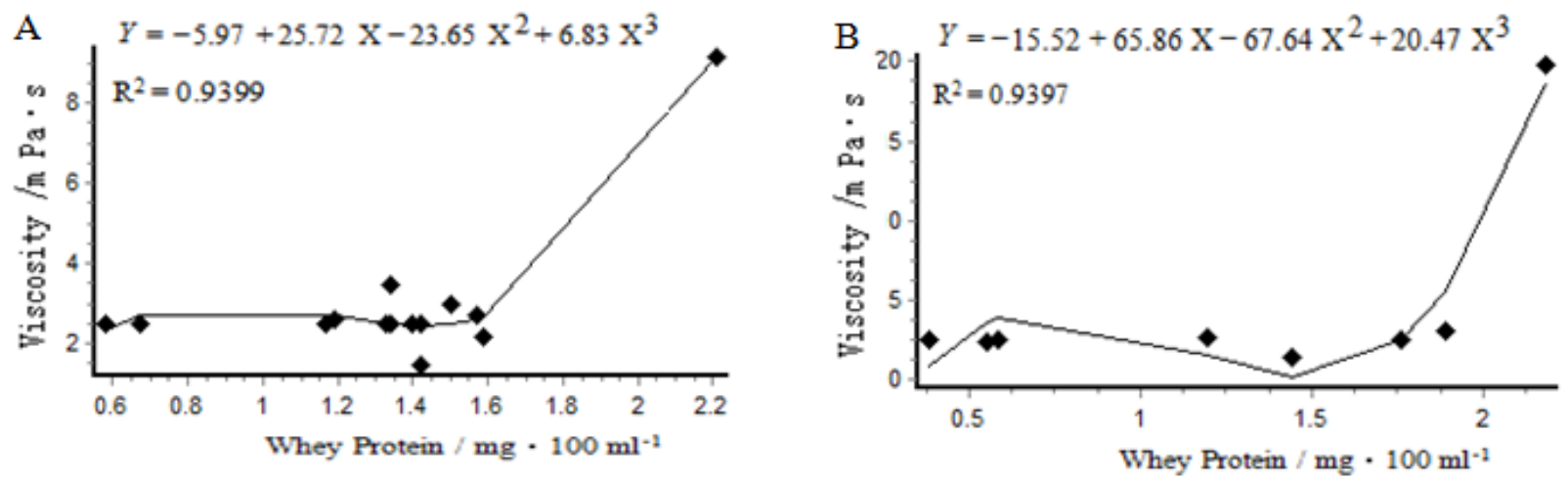

Note: points in figure showed a certain content of whey protein corresponded to a value of milk viscosity at the same storage temperature and time.

Figure 4. Correlation between milk viscosity and whey protein content during storage. A and B were the correlation between the content of Whey Protein and viscosity in the temperature of $10^{\circ} \mathrm{C}$ and $20^{\circ} \mathrm{C}$, respectively. 

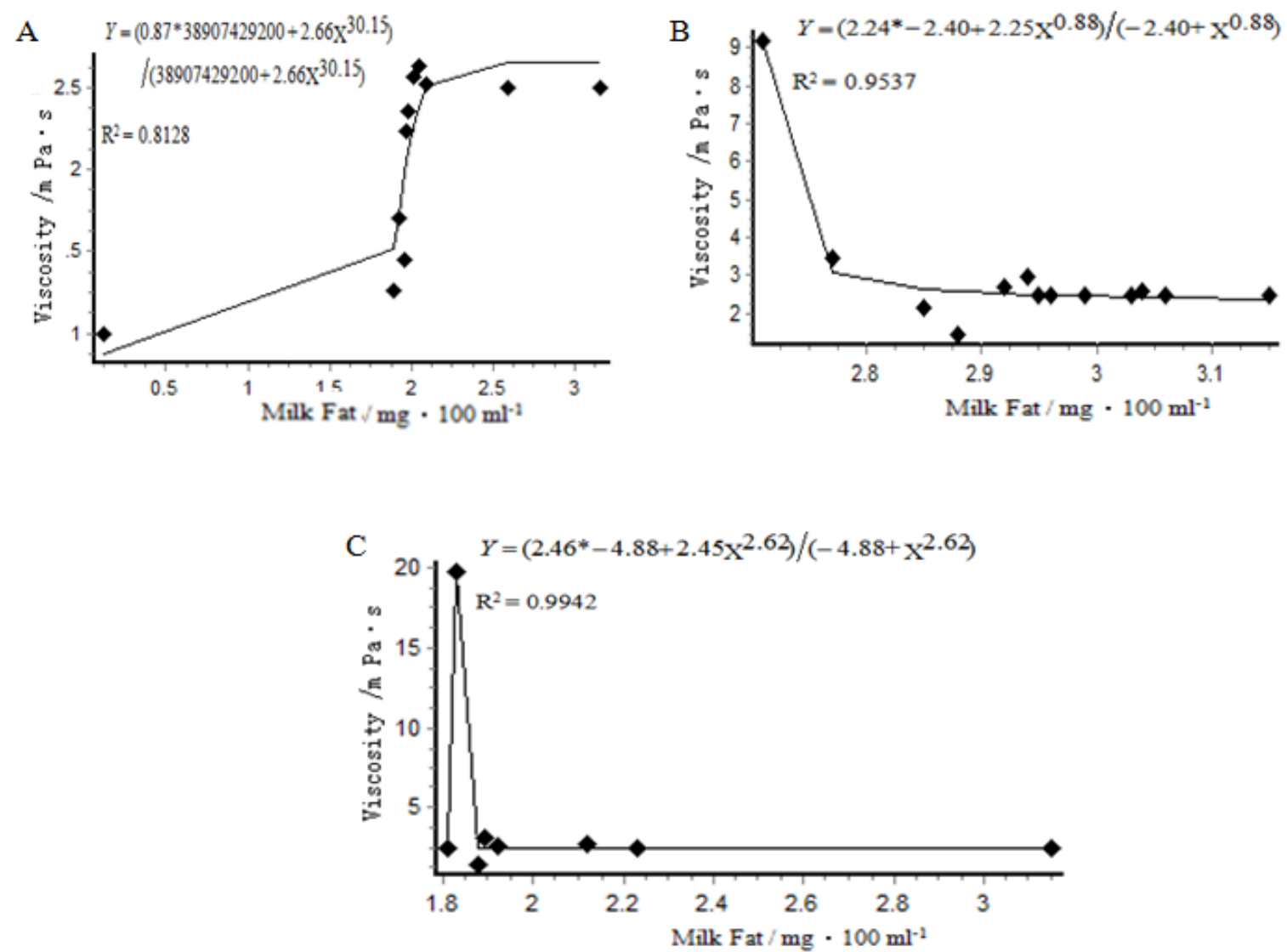

Note: points in figure showed a certain content of milk fat corresponded to a value of milk viscosity at the same storage temperature and time.

Figure 5. Correlation between milk viscosity and milk fat content during storage. A, B and $\mathrm{C}$ were the correlation between the content of Whey Protein and viscosity in the temperature of $2-5^{\circ} \mathrm{C}, 10^{\circ} \mathrm{C}$ and $20^{\circ} \mathrm{C}$, respectively.

\subsection{Relationship between Milk Fat Content and Milk Viscosity during Storage}

The model had been proposed to find the relationship between milk fat content and viscosity at the temperature of $2-5^{\circ} \mathrm{C}, 10^{\circ} \mathrm{C}$ and $20^{\circ} \mathrm{C}$ by method of Morgan Mercer Florin and model equations were as follows: Equation 4A, Equation $4 \mathrm{~B}$ and Equation $4 \mathrm{C}$. The models had good fit with high correlation coefficients $\left(\mathrm{R}^{2}=0.8128,0.9537\right.$ and 0.9942 , respectively). The three models could well explain the relationship between milk fat content and viscosity at a significance level of $0.0061,0.0001$ and 0.0001 , respectively (Fig. 5A, Fig. 5B and Fig. 5C).

$Y=\left(0.87 * 389074292.00+2.66 \mathrm{X}^{30.15}\right) /\left(389074292.00+2.66 \mathrm{X}^{30.15}\right)$

(Equation 4A)

Where; $\mathrm{X}=$ milk fat content $\left(\mathrm{g} \cdot 100 \mathrm{ml}^{-1}\right)$ at the temperature of $4^{\circ} \mathrm{C}, \mathrm{Y}=$ the value of viscosity $(\mathrm{mpa} \cdot \mathrm{s})$.

$$
Y=\left(2.24 *-2.40+2.25 \mathrm{X}^{0.88}\right) /\left(-2.40+\mathrm{X}^{0.88}\right)
$$

(Equation 4B)

Where; $\mathrm{X}=$ milk fat content $\left(\mathrm{g} \cdot 100 \mathrm{ml}^{-1}\right)$ at the temperature of $10^{\circ} \mathrm{C}, \mathrm{Y}=$ the value of viscosity $(\mathrm{mpa} \cdot \mathrm{s})$.

$Y=\left(2.46 *-4.88+2.45 \mathrm{X}^{2.62}\right) /\left(-4.88+\mathrm{X}^{2.62}\right)$

(Equation 4C)
Where; $\mathrm{X}=$ milk fat content $\left(\mathrm{g} \cdot 100 \mathrm{ml}^{-1}\right)$ at the temperature of $20^{\circ} \mathrm{C}, \mathrm{Y}=$ the value of viscosity (mpa $\left.\cdot \mathrm{s}\right)$.

\section{Discussion}

\subsection{Analysis of Viscosity Change}

Several physicochemical changes occurred in milk along with storing time lengthening on account of the growth of bacteria. Spherical caseins exhibited a strong tendency to self-assemble into linear casein during the process of milk acidification. The denatured whey proteins, being more susceptible to associate with casein micelles, aggregated due to the reduction of their repulsive charge and acted as bridging material among casein micelles. All of these could lead to an increase in milk viscosity ${ }^{[17]}$. However, viscosity decreased because of the continuing proteolysis and the growth of mold in the process of neutralization stage of milk deterioration. As duration lengthened, milk protein interacted with calcium phosphate to form hydrated protein that caused a rapid recovery in viscosity ${ }^{[19]}$. Together, the milk viscosity experienced a trend of increase-decrease-highest at the temperature of $10^{\circ} \mathrm{C}$ and $20^{\circ} \mathrm{C}$. It was noteworthy that the milk viscosity at $2-5^{\circ} \mathrm{C}$ only 
experienced a trend of decrease-highest because a lower temperature was beneficial to maintain little change in the viscosity.

\subsection{Effect of Storage Temperature and Time on Viscosity}

In this study, the milk viscosity began to increase on the third day (about 48 hours later) at the temperature of $2-5^{\circ} \mathrm{C}$, while timing of the increase in viscosity appeared at the $42^{\text {nd }}$ hour and $24^{\text {th }}$ hour at the temperature of $10^{\circ} \mathrm{C}$ and $20^{\circ} \mathrm{C}$. It showed that a lower temperature could postpone the time for viscosity change. The reason for that would be the lower temperature helped to maintain water retention ability of macromolecular substances in milk.

Viscosity remained quite steady at the $42^{\text {nd }}$ hour at the temperature of $10^{\circ} \mathrm{C}$, while obvious change appeared at the same time in the temperature of $20^{\circ} \mathrm{C}$ for the reason that a lower temperature condition was the key factor to result in the recovery of viscosity. It was also the reason that the models between viscosity and macromolecular substances including milk protein, casein and whey protein were established difficultly in the temperature of $2-5^{\circ} \mathrm{C}^{[20,21]}$.

The viscosity of milk remained relatively stable when deterioration in milk quality not occurred because milk fat particles and milk protein micelles distributed uniformly. While viscosity increased because casein denatured and then stretched to linear form when a large amount of lactic acid produced during the follow-up period ${ }^{[5,19]}$. After that, small amounts of curd floated on the top of the milk, and milk was delaminated and deposited slightly though milk samples shook and would maintain the viscosity not fluctuated. Milk presented a change visible with the naked eye after the value of viscosity reached minimum. Viscosity increased greatly as a lot of clumpy curds in milk appeared with the further extension of storage time, and generated big errors from equipment measure.

\subsection{Effect of Macromolecular Substances in Milk on Viscosity}

The change in milk viscosity was depended on the contents of milk fat and milk protein. Shaker et al. found that the content of milk fat and viscosity rose first and then decreased when the total solids content of milk was fixed during storage ${ }^{[22]}$. Işıklı et al. suggested that milk viscosity would also rise correspondingly by improving water binding capacity of milk when the content of milk protein increased ${ }^{[23]}$. Casein moleculars contained hydrophobic groups that form space grid structure due to the existence of the electrostatic interactions and calcium ion, contributing to a change in milk viscosity. The structure of casein could also make a difference in milk viscosity. Milk protein secondary structure and above suffered damages during the process of storage, but the primary structure not. Thus the viscosity increased because the protein primary structure could enlarge fluid volume ${ }^{[24,25]}$.

The interactions among these macromolecular substances could cause a change in viscosity during the process of deterioration of milk ${ }^{[9,26]}$. And the exponential models with high value of $R^{2}\left(R^{2}>0.8000\right)$ were the best to predict the dependency of viscosity upon the content of macromolecular substances. So mathematical models could well reflect the relationships between viscosity and macromolecular substances from milk and explain the mechanism of period of deterioration of milk. The models were perhaps the most widely employed model for non-Newtonian liquids and were used extensively to describe the flow properties of liquids in theoretical analysis as well as in practical engineering applications.

\section{Conclusions}

The relationships between the viscosity and the contents of macromolecular substances from milk were described in the temperature of $2-5^{\circ} \mathrm{C}, 10^{\circ} \mathrm{C}$ and $20^{\circ} \mathrm{C}$ in the process of storage. In light of the result, milk viscosity experienced a trend of increase-decrease-highest at the temperature of $10^{\circ} \mathrm{C}$ and $20^{\circ} \mathrm{C}$ in stage of the experimental storage. At $2-5^{\circ} \mathrm{C}$, milk viscosity only experienced a trend of decrease-highest. The correlation models based on the viscosity and the contents of macromolecular substances had good fit with high correlation coefficients $\left(\mathrm{R}^{2}>0.8000\right) .8$ models that had been established could well explain the relationships between the viscosity and the contents of macromolecular substances at a significance level which was less than or equal to 0.0067 , which contributed to a better understanding of the change of milk system during storage in view to provide tools to develop high quality dairy products with desirable characteristics, and could also be useful in quality control and real-time monitoring of deterioration of the raw milk.

\section{Acknowledgements}

This work was supported by the Shaanxi science and technology plan projects of China (2014KJXX-51), the China postdoctoral science foundation (2015M570811), the National twelfth "Five Year" science and technology support project (2012BAD12B07) and the fundamental research funds for the central universities of China (GK201502008).

\section{REFERENCES}

[1] Singh, R.; De, S.; Belkheir, A. Avena sativa (Oat), A potential neutraceutical and therapeutic agent: an overview. Critical Reviews in Food Science and Nutrition 2011, 53: 126-144.

[2] Saravacos, G. Effect of temperature on viscosity of fruit juices and purees. Journal of Food Science 1970, 35: 122-125.

[3] Deboni, T. M.; Bündchen, M.; Junior, C. V.; Hotza, D.; Piletti, 
R.; Quadri, M. G. N. Effect of the processing steps on cactus juice production. Food and Bioprocess Technology 2013, 7: 990-1000.

[4] Krokida, M. K.; Maroulis, Z. B.; Saravacos, G. D. Rheological properties of fluid fruit and vegetable puree products: compilation of literature data. International Journal of Food Properties 2001, 4: 179-200.

[5] Gentès, M. C.; St-Gelais, D.; Turgeon, S. L. Gel formation and rheological properties of fermented milk with in situ exopolysaccharide production by lactic acid bacteria. Dairy Science \& Technology 2011, 91: 645-661.

[6] Ismail, A. A.; El Deeb, S. A. Effect of Heat Processing, Storing and Homogenization on the Viscosity, Opacity and Stability of Cow and Buffalo Milks. European Food Research and Technology 1973, 152: 202-207.

[7] Devold, T. G.; Brovold, M. J.; Langsrud, T.; Vegarud, G. E. Size of native and heated casein micelles, content of protein and minerals in milk from Norwegian Red Cattle-effect of milk protein polymorphism and different feeding regimes. International Dairy Journal 2000, 10: 313-323.

[8] Simuang, J.; Chiewchan, N.; Tansakul, A. Effects of fat content and temperature on the apparent viscosity of coconut milk. Journal of Food Engineering 2004, 64: 193-197.

[9] Frederiksen, P. D.; Hammershøj, M.; Bakman, M.; Andersen, P. N.; Andersen, J. B.; Qvist, K. B.; Larsen, L. B. Variations in coagulation properties of cheese milk from three Danish dairy breeds as determined by a new free oscillation rheometry-based method. Dairy Science \& Technology 2011, 91: 309-332.

[10] Sfakianakis, P.; Topakas, E.; Tzia, C. Comparative Study on High-Intensity Ultrasound and Pressure Milk Homogenization: Effect on the Kinetics of Yogurt Fermentation Process. Food and Bioprocess Technology 2015, 8: 548-557.

[11] Caprita, R.; Caprita, A.; Benscik, I.; Cretescu, I. The Influence of Milk Protein Content on the Surface Tension and Viscosity. Acta Veterinaria Scandinavica 2003, 44: 86.

[12] Zhao, Z. T.; Corredig, M. Changes in the physico-chemical properties of casein micelles in the presence of sodium chloride in untreated and concentrated milk protein. Dairy Science \& Technology 2015, 95: 87-99.

[13] Dalgleish, D. G.; Corredig, M. The structure of the casein micelle of milk and its changes during processing. Annual Review of Food Science Technology 2012, 3: 449-467.

[14] Holt, C.; Carver, J. A.; Ecroyd, H.; Thorn, D. C. Invited review: Caseins and the casein micelle: their biological functions, structures, and behavior in foods. Journal of Dairy Science 2013, 96: 6127-6146.
[15] Horne, D. S. Formation and structure of acidified milk gels. International Dairy Journal 1999, 9: 261-268.

[16] Horne, D. S.; Davidson, C. M. Influence of heat treatment on gel formation in acidified milks. In Protein and fat globule modifications by heat treatment, homogenization and other technological means for high quality dairy products. IDF Special Issue 9303, Brussels: International Dairy Federation 1993, 267-276.

[17] Sfakianakis, P.; Tzia, C. Conventional and innovative processing of milk for yogurt manufacture; development of texture and flavor: a review. Foods 2014, 3: 176-193.

[18] Ellman, G. L. The biuret reaction: changes in the ultraviolet absorption spectra and its application to the determination of peptide bonds. Analytical biochemistry 1962, 3: 40-48.

[19] Mishra, S.; Mishra, H. N. Effect of Synbiotic Interaction of Fructooligosaccharide and Probiotics on the Acidification Profile, Textural and Rheological Characteristics of Fermented Soy Milk. Food and Bioprocess Technology 2013, 6: 3166-3176.

[20] Guyomarc'h, F.; Jemin, M.; Tilly, V. L.; Madec, M. N.; Famelart, M. H. Role of the heat-induced whey protein/ $\kappa$-casein complexes in the formation of acid milk gels: a kinetic study using rheology and confocal microscopy. Journal of Agricultural and Food Chemistry 2009, 57: 5910-5917.

[21] Jacob, M.; Nobel, S.; Jaros, D.; Rohm, H. Physical properties of acid milk gels: acidification rate significantly interacts with crosslinking and heat treatment of milk. Food Hydrocolloid 2011, 25: 928-934.

[22] Shaker, R. R.; Jumah, R. Y.; Abu-Jdayil, B. Rheological properties of plain yogurt during coagulation process: impact of fat content and preheat treatment of milk. Journal of Food Engineering 2000, 44: 175-180.

[23] Işı1klı， N. D.; Dönmez, M. N.; Kozan, N.; Karababa, E. Rheological properties of salep powder-milk mixture. Journal of Food Science and Technology 2015, 52: 1-9.

[24] Law, W. K.; Frizzell, L. A.; Dunn, F. Determination of the nonlinearity parameter $\mathrm{B} / \mathrm{A}$ of biological media. Ultrasound in Medicine and Biology 1985, 11: 307-318.

[25] Zhang, J.; Kuhlenschmidt, M. S.; Dunn, F. Influences of structural factors of biological media on the acoustic nonlinearity parameter B/A. Journal of the Acoustical Society of America 1991, 89: 80-91.

[26] Ikonen, T.; Morri, S.; Tyrisevä, A. M.; Ruottinen, O.; and Ojala, M. Genetic and phenotypic correlations between milk coagulation properties, milk production traits, somatic cell count, casein content, and $\mathrm{pH}$ of milk. Journal of Dairy Science 2004, 87: 458-467. 